\title{
SAFETY IN NEW ZEALAND WEED BIOCONTROL: A NATIONWIDE PATHOGEN SURVEY FOR IMPACTS ON NON-TARGET PLANTS
}

\author{
N.W. WAIPARA ${ }^{1}$, J. BARTON ${ }^{2}$, L.A. SMITH ${ }^{3}$, H.M. HARMAN ${ }^{4}$, \\ C.J. WINKS ${ }^{1}$, B. MASSEY ${ }^{1}$, J.P. WILKIE ${ }^{1}$, A.F. GIANOTTI ${ }^{1}$ and \\ M.G. CRIPPS ${ }^{5}$
}

\author{
${ }^{1}$ Landcare Research, Private Bag 92170, Auckland, New Zealand \\ ${ }^{2} 467$ Rotowaro Rd, RD1, Huntly, New Zealand \\ ${ }^{3}$ Landcare Research, P.O. Box 69, Lincoln, New Zealand \\ ${ }^{4}$ MAFBNZ, P.O. Box 2526, Wellington, New Zealand \\ ${ }^{5}$ Lincoln University, P.O. Box 84, Lincoln, New Zealand
}

Corresponding author: nick.waipara@arc.govt.nz.

\begin{abstract}
The accuracy of host range testing in weed biocontrol programmes using plant pathogens has been questioned prompting a research programme into the field safety record of pathogens used for weed biocontrol in New Zealand. Nationwide disease surveys were conducted from 2000-2009, and focused on species closely related to target weeds and therefore potentially most at risk of attack. These surveys identified pathogens associated with any disease symptoms observed on non-target hosts. Disease damage attributable to biocontrol agents was observed on two non-target plants. Pustules of the blackberry rust, Phragmidium violaceum, were found on the endemic Rubus species, R. cissoides (bush lawyer, tataramoa) at one location. This result was predicted from host range safety tests conducted prior to its arrival in New Zealand. No non-target damage was observed in the remaining case studies, confirming to date that all biocontrol pathogens are highly host specific to their target weeds. Keywords: biological control, disease, specificity, risk, environmental safety.
\end{abstract}

\section{INTRODUCTION}

Concerns about potential non-target impacts and risks associated with classical biological control of weeds (Howarth 1991; Simberloff \& Stiling 1996) are resulting in tighter controls over the importation and release of biological control agents worldwide (Sheppard et al. 2003). In New Zealand, the Hazardous Substances and New Organisms (HSNO) Act (1996) administered by the Environmental Risk Management Authority (ERMA), requires a rigorous risk analysis for the potential introduction of biological control agents that considers the environmental risk of each proposed agent to attack non-target plant species (Fowler et al. 2000; Paynter et al. 2004). Host testing of all pathogens for weed biocontrol is currently based on the internationally accepted host range testing systems that help delineate the host-range for potential agents (Wapshere 1974; Briese \& Walker 2002; Louda et al. 2003). Although biological control of invasive weeds is often perceived as environmentally safe, there have been reported cases of damage to non-target plants by some introduced invertebrate agents (e.g. Pemberton 1995; Louda et al. 1997, 2003). International reviews of weed biocontrol introductions have shown that of the almost 400 invertebrates and pathogens introduced as classical biocontrol agents for weeds, only 29 invertebrate species $(7.25 \%)$ have been reported from non-target plants (Barton 2004). Furthermore, the few reviews of weed biocontrol safety that have specifically focused on pathogens have been unanimous in concluding 
that they have proved extremely safe (Evans 2000; Goettel et al. 2001). A comprehensive global assessment by Barton (2004) determined there were no reports of deliberately introduced fungi unexpectedly attacking non-target plants after release. However, past investigations of non-target effects of weed biocontrol agents in New Zealand have been sporadic, with systematic surveys typically carried out only at a local scale if a report of suspected non-target damage was received (Paynter et al. 2004). No systematic field surveys of introduced (deliberate or otherwise) plant pathogens on non-target species had been undertaken in New Zealand. Evaluating weed biological control projects is essential to improve our ability to predict the impact and safety of future introductions and, therefore, underpin the continued use of biological control as a tool against damaging invasive weeds (Paynter et al. 2004).

The research reported here is the first systematic field survey of non-target plants undertaken in New Zealand. The aim was to specifically look for plant pathogens with biocontrol potential that had been introduced (deliberately or not).

\section{MATERIALS AND METHODS}

Surveys were conducted throughout New Zealand, and focused on plants that are closely related to the target weeds and are therefore most at risk of non-target attack (Barton 2004; Paynter et al. 2004). The objective was to search for any disease damage caused by the following five plant pathogens, all of which have been deliberately, accidentally or autonomously introduced to New Zealand.

1. The white smut fungus, Entyloma ageratinae Barreto \& Evans was released in 1998 for the biocontrol of mist flower, Ageratina riparia (Regel) R.M.King \& H.Rob (Barton et al. 2007). This pathogen was searched for on the most closely related host present in New Zealand, the invasive Mexican devil weed, Ageratina adenophora (Spreng.) R.M.King \& H.Rob.

2. Strains of the violet bramble leaf or blackberry rust, Phragmidium violaceum (Schultz) G. Winter, were first officially released in Australia in 1991 for the biocontrol of blackberry Rubus fruticosus L. aggregate. Strains had already appeared there earlier in 1984 (Marks et al. 1984) due to illegal introduction(s) that consequently resulted in its arrival in New Zealand in 1990 (McKenzie 1998). The New Zealand introduction was potentially autonomous via its wind blown spores (Gomez et al. 2006). Evergreen blackberry (Rubus laciniatus Willd.), three commercially grown Rubus species, namely raspberry ( $R$. idaeus L.), boysenberry ( $R$. ursinus $x$ idaeus Chamisso \& Schlenhtendal) and loganberry ( $R$. ursinus loganobaccus Bailey), and three endemic Rubus species (bush lawyer, tataramoa), namely $R$. cissoides A. Cunn., $R$. australis G.Forst) and $R$. schmidelioides A.Cunn., were surveyed for rust infection over three periods (Table 1), 2000-2001, 2004-2006 and 2008-2009, the latter at two sites.

3. Puccinia hieracii var. piloselloidarum (Probst) Jørst. was either illegally or accidentally introduced to New Zealand (McKenzie 1998), after originally being scoped as a potential biocontrol agent against mouse-eared hawkweed (Hieracium pilosella L.) (Jenkins 1995a,b). The three most common and related Hieracium species in New Zealand, field hawkweed (H. caespitosum Durmort), king devil hawkweed (H. praealtum Gochant) and tussock hawkweed (H. lepidulum (Stenstroem) Omang.), were checked for the rust.

4. In 2000, the rust Puccinia myrsiphylli G.Winter was released in Australia for the biocontrol of bridal creeper/smilax (Asparagus asparagoides (L.) W. Wight). By 2005 it was first recorded in New Zealand (Waipara et al. 2006) and by 2008 had spread over most of the invasive range of the weed (Harman et al. 2008). Another closely related and invasive weed, climbing asparagus (Asparagus scandens Thunb.), was surveyed for $P$. myrsiphylli infection. This case study was a belated inclusion due to the discovery of the rust after the other non-target surveys had been initiated.

5. Californian thistle rust, Puccinia punctiformis (Str.) Röhl, was first recorded in New Zealand as early as 1881 (Cunningham 1927). Subsequently it was used as an augmentative biocontrol agent against Californian thistle Cirsium arvense L. Scop., and a 
recent comparative survey has shown that this pathogen occurs in New Zealand at levels similar to its native range of Europe (Cripps et al. 2009). Three related thistle species, marsh thistle (Cirsium palustre L. Scop.), Scotch thistle (Cirsium vulgare (Savi) Ten.) and nodding thistle (Carduus nutans L.), were checked for presence of P. punctiformis.

Where possible, field sites were selected where the agent, the target weed and the potential non-target species were all present. These sites maximise the potential for inoculum to 'spill over' onto any proximate and susceptible non-target species nearby. However, as all five pathogens can disperse via airborne spores, it was assumed that any substantial stand of the non-target plant was exposed to the agent, even if several kilometres away from potential inoculum sources. Details of field sites, year of inspection and number of plants inspected are provided in Table 1.

Any diseased plant materials (leaf, shoot, flower, fruit) were collected and the causative pathogens associated with the visible symptoms were identified either by direct examination or by cultural isolation. A dissecting microscope was used to search necrotic areas for the sporulation of rust/smut pustules. Methods outlined previously (Waipara et al. 2009) were used to isolate other pathogenic fungi from diseased tissues when required. Voucher specimens were deposited into the Landcare Research PDD herbarium at Auckland.

\section{RESULTS}

Pustules containing the diagnostic teliospores of $P$. violaceum were identified sporulating on the leaves of two individual plants of endemic bush lawyer ( $R$. cissoides). Therefore, non-target attack by the rust was confirmed during the field surveys of Rubus plants (Table 2). Visible infection of $R$. cissoides was infrequent, with the rust being found on only 2 out of the 132 (1.5\%) plants of that species examined during 2004-2006, and no infection being recorded in subsequent checks (2008-2009). Both infected plants were located at the same field site (Mt Maroanui, north of Taupo). The site contained many blackberry plants, heavily infected with the rust, growing directly below the infected $R$. cissoides plants. The close proximity between target and non-target plants potentially contributed to this result. Nevertheless, at 14 other North Island sites, infected blackberry plants were also found growing in close proximity to $R$. cissoides, but without signs of any cross infection. The two $R$. cissoides plants found with pustules of $P$. violaceum displayed only minor disease symptoms; there were only a few infected leaves and these leaves only had a small number of lesions attributable to the rust. To date, the strain/s of blackberry rust present in New Zealand are having a negligible impact on this native species (J. Barton \& N. Waipara, unpubl. data).

While not a specified target weed for $P$. violaceum, the evergreen (cut leaf) blackberry, $R$. laciniatus, was also found to be infected by the rust in 2000-2002 and 2004-2006 (Table 2). This result further demonstrated the rust's broad host range and its potential to infect different Rubus species. None of the three commercially cultivated Rubus species were infected by $P$. violaceum, which was consistent with predictions drawn from earlier host tests (Bruzzese \& Hasan 1986b).

No non-target infection was found by the pathogens, Entyloma ageratinae, Puccinia hieracii piloselloidarum, Puccinia myrsiphylli and Puccinia punctiformis on any of the non-target plants examined, despite positive infection being observed on many of the host plants (Table 2).

The disease survey also identified four other rust pathogens and Septoria rubi damaging Rubus hosts (Table 3).

The host-specific fungus Phaeoramularia eupatorii-odorati (Yen) Liu \& Guo was observed on 40 Mexican devil weed plants at all 7 field sites (Table 3). This leaf pathogen produces necrotic leaf lesions that can resemble damage by the mist flower smut E. ageratinae, and Barton (2004) noted several false alarms that the smut was attacking the wrong Ageratina species.

Other pathogens that resembled potential non-target attack were also identified in the surveys (Table 3). For example, the rust Puccinia cnici H. Mart. was recorded on 
TABLE 1: Number of field sites (by region), assessment dates (year) and samples ( $N=$ number of plants) surveyed for disease on non-target species(NT) caused by plant pathogens that had been introduced for biocontrol of target weed species( $T)$.

\begin{tabular}{|c|c|c|c|c|c|}
\hline Pathogen & Plant & Region $^{1}$ & Sites & Year & $(\mathrm{N})$ \\
\hline Entyloma & Mist flower ${ }^{(T)}$ & 1,2 & 7 & 2005 & 35 \\
\hline \multirow[t]{4}{*}{ ageratinae } & & & 3 & 2007 & 12 \\
\hline & Mexican devil weed $^{(\mathrm{NT})}$ & 1,2 & 7 & 2005 & 35 \\
\hline & & & 3 & 2007 & 12 \\
\hline & Total Ageratina spp. & 2 & 7 & & 94 \\
\hline Phragmidium & Blackberry $^{(\mathrm{T})}$ & $2,4,5,7-14$ & 22 & $2000-02$ & $24^{2}$ \\
\hline \multirow[t]{12}{*}{ violaceum } & & $1-9$ & 25 & 2004-06 & $188^{2}$ \\
\hline & & 2 & 2 & 2008-09 & $12^{2}$ \\
\hline & Evergreen blackberry $^{(\mathrm{NT})}$ & 10,14 & 2 & $2000-02$ & 2 \\
\hline & & 5,8 & 2 & 2004-06 & $12^{2}$ \\
\hline & Raspberry $^{(\mathrm{NT})}$ & 4,6 & 3 & 2004-06 & $30^{2}$ \\
\hline & Boysenberry $^{(\mathrm{NT})}$ & 4,6 & 2 & 2004-06 & $20^{2}$ \\
\hline & Loganberry $^{(\mathrm{NT})}$ & 4,6 & 2 & 2004-06 & $20^{2}$ \\
\hline & R. australis a $^{(\mathrm{NT})}$ & $1,3,7,8$ & 5 & 2004-06 & 31 \\
\hline & R. cissoides $^{(\mathrm{NT})}$ & $1-9$ & 26 & 2004-06 & $132^{2}$ \\
\hline & & & 2 & 2008-09 & 3 \\
\hline & R. schmidelioides ${ }^{(\mathrm{NT})}$ & $1,5-9$ & 16 & 2004-06 & $69^{2}$ \\
\hline & Total Rubus spp. & 14 & 35 & & $543^{2}$ \\
\hline Puccinia hieracii & Mouse-eared hawkweed ${ }^{(\mathrm{T})}$ & $7,11,12,14$ & 10 & 2005 & 100 \\
\hline \multirow[t]{4}{*}{ piloselloidarum } & Field hawkweed $^{(\mathrm{NT})}$ & 11,14 & 3 & 2005 & 30 \\
\hline & King devil hawkweed ${ }^{(\mathrm{NT})}$ & 12,14 & 7 & 2005 & 70 \\
\hline & Tussock hawkweed $^{(\mathrm{NT})}$ & $11,12,14$ & 6 & 2005 & 60 \\
\hline & Total Hieracium spp. & 4 & 26 & & 260 \\
\hline Puccinia & Bridal creeper ${ }^{(T)}$ & 1,2 & 5 & 2007-09 & 15 \\
\hline \multirow[t]{2}{*}{ myrsiphylli } & Climbing asparagus $^{(\mathrm{NT})}$ & 1,2 & 5 & 2007-09 & 27 \\
\hline & Total Asparagus spp. & 2 & 5 & & 42 \\
\hline Puccinia & Californian thistle ${ }^{(\mathrm{T})}$ & 3,4 & 9 & 2001-04 & 172 \\
\hline \multirow[t]{6}{*}{ punctiformis } & & $2-4,8,12,14$ & 20 & 2007-09 & 55 \\
\hline & Marsh thistle $\mathrm{e}^{(\mathrm{NT})}$ & 2 & 1 & 2007-09 & 4 \\
\hline & Scotch thistle ${ }^{(\mathrm{NT})}$ & 3,4 & 9 & 2001-04 & 29 \\
\hline & & $2-4,8,12,14$ & 20 & 2007-09 & 25 \\
\hline & Nodding thistle $^{(\mathrm{NT})}$ & 2,3 & 4 & 2007-09 & 16 \\
\hline & Total thistles & 7 & 32 & & 301 \\
\hline
\end{tabular}

${ }_{1}^{1}$ Key to region: 1=Northland, 2=Auckland, 3=Waikato//King Country, 4=Coromandel/ Bay of Plenty, 5=Gisborne, 6=Hawke's Bay, 7=Taupo, 8=Taranaki, 9=Wanganui/ Manawatu, 10=Wellington, 11=Nelson/Marlborough, 12=Canterbury, 13=West Coast, $14=$ Otago/Southland.

${ }^{2}$ Estimated minimum number. Where Rubus plants formed dense thickets the number of plants examined was recorded as 'greater than' this minimum figure. 
TABLE 2: Occurrences of positive infection on target and non-target plant species caused by plant pathogens introduced for weed biocontrol. $\mathrm{N}=$ number of plants exhibiting infection by the pathogen/total number of plants examined.

\begin{tabular}{lccc}
\hline Plant species & Year & Pathogen & $\mathrm{N}$ \\
\hline Mist flower & 2005 & Entyloma ageratinae & $35 / 35$ \\
& 2007 & Entyloma ageratinae & $12 / 12$ \\
Blackberry & $2000-02$ & Phragmidium violaceum & $22 / 24$ \\
& $2004-06$ & Phragmidium violaceum & $116 / 188$ \\
& $2008-09$ & Phragmidium violaceum & $3 / 3$ \\
Evergreen blackberry & $2000-02$ & Phragmidium violaceum & $1 / 2$ \\
& $2004-06$ & Phragmidium violaceum & $1 / 12$ \\
R. cissoides & $2004-06$ & Phragmidium violaceum & $2 / 132$ \\
& $2008-09$ & - (no non-target infection) & $0 / 3$ \\
Mouse-eared hawkweed & 2005 & Puccinia hieracii piloselloidarum & $27 / 100$ \\
Bridal creeper & $2007-09$ & Puccinia myrsiphylli & $15 / 15$ \\
Californian thistle & $2001-04$ & Puccinia punctiformis & $153 / 172$ \\
& $2007-09$ & Puccinia punctiformis & $19 / 55$ \\
& $2007-09$ & Puccinia punctiformis & $19 / 55$ \\
\hline
\end{tabular}

Scotch thistle and produced superficially similar symptoms to that of $P$. punctiformis on Californian thistle. All other pathogens are previously reported primary and secondary pathogens on their respective hosts (Pennycook 1989). These included Alternaria spp., Botrytis cinerea, Colletotrichum gloeosporioides, Phomopsis sp. and two powdery mildews (Erysiphe cichoracearum and Oidium sp.). Most were associated with very minor leaf/shoot necroses and are cosmopolitan species in New Zealand (Pennycook 1989).

\section{DISCUSSION}

Of the five pathogens surveyed, non-target damage was observed only in the Rubus case study. Phragmidium violaceum was not deliberately introduced to New Zealand for blackberry biocontrol and the strict host specificity protocols required by ERMA for the release of all biocontrol agents would have most likely precluded its official release here. Field infection of the blackberry rust on $R$. cissoides was predicted from previous host range testing when the pathogen was first being considered as a potential biocontrol agent for blackberry in Australia (Bruzzese \& Hasan 1996a). Laboratory inoculations of native Australian and New Zealand Rubus species showed that $R$. gunnianus from Tasmania, $R$. schmidelioides and $R$. cissoides from New Zealand were all moderately susceptible to $P$. violaceum (Bruzzese \& Hasan 1996a). These studies concluded that damage to $R$. schmidelioides and $R$. cissoides could be expected if the rust reached New Zealand, but was unlikely to affect other endemic and commercial Rubus species (Bruzzese \& Hasan 1996a,b). In contrast to the Australian tests, the present field surveys did not detect any non-target damage on $R$. schmidelioides. This may indicate environmental conditions in New Zealand are rarely, or not at all, conducive to infection by the rust, but future checks of this species are recommended given the Australian test results. The infection of evergreen blackberry by $P$. violaceum has previously been reported (Osterbauer et al. 2005), but is not considered deleterious given that this species is also invasive in New Zealand.

Despite its clear lack of host specificity, proponents of the blackberry biocontrol programme in Australia argued successfully that the rust should be released because "although the effect of the rust on populations of the susceptible species of Australian 
TABLE 3: Other pathogens observed on host plants. $\mathbf{N}=$ number of plants exhibiting infection/total number of plants examined.

\begin{tabular}{|c|c|c|c|}
\hline Plant species & Year & Pathogen & $\mathrm{N}$ \\
\hline \multirow[t]{2}{*}{ Mexican devil weed } & 2005 & Phaeoramularia eupatorii-odorati & $29 / 35$ \\
\hline & 2007 & Phaeoramularia eupatorii-odorati & $11 / 12$ \\
\hline \multirow[t]{3}{*}{ Blackberry } & $2000-02$ & Kuehneola uredinis & $1 / 24$ \\
\hline & 2004-06 & Kuehneola uredinis & $83 / 188$ \\
\hline & 2008-09 & Septoria rubi & $1 / 3$ \\
\hline \multirow[t]{2}{*}{ Evergreen blackberry } & $2000-02$ & Kuehneola uredinis & $1 / 2$ \\
\hline & 2004-06 & Kuehneola uredinis & $10 / 12$ \\
\hline Raspberry & 2004-06 & Phragmidium rubi-idaei & $30 / 30$ \\
\hline Loganberry & 2004-06 & Kuehneola uredinis & $10 / 20$ \\
\hline \multirow[t]{2}{*}{$R$. cissoides } & 2004-06 & Kuehneola uredinis & $3 / 132$ \\
\hline & 2004-06 & Hamaspora australis & $8 / 132$ \\
\hline \multirow[t]{3}{*}{ R. schmidelioides } & 2004-06 & Kuehneola uredinis & $8 / 69$ \\
\hline & 2004-06 & Hamaspora australis & $23 / 69$ \\
\hline & 2004-06 & Uredo sp. & $14 / 69$ \\
\hline Mouse-eared hawkweed & 2005 & Erysiphe cichoracearum & $9 / 100$ \\
\hline Field hawkweed & 2005 & Phomopsis sp. & $1 / 30$ \\
\hline King devil hawkweed & 2005 & Erysiphe cichoracearum & $1 / 70$ \\
\hline Tussock hawkweed & 2005 & Ramularia sp. & $1 / 60$ \\
\hline Bridal creeper & 2007-09 & Colletotrichum gloeosporioides & $9 / 15$ \\
\hline Climbing asparagus & 2007-09 & Colletotrichum gloeosporioides & $8 / 27$ \\
\hline \multirow[t]{4}{*}{ Californian thistle } & 2001-04 & Phoma exigua & $31 / 172$ \\
\hline & 2007-09 & Phoma exigua & $9 / 55$ \\
\hline & 2007-09 & Alternaria spp. & $5 / 55$ \\
\hline & 2007-09 & Colletotrichum sp. & $2 / 55$ \\
\hline Marsh thistle & 2007-09 & Botrytis cinerea & $1 / 4$ \\
\hline \multirow[t]{4}{*}{ Scotch thistle } & 2001-04 & Puccinia cnici & $19 / 29$ \\
\hline & 2001-04 & Oidium sp. & $3 / 29$ \\
\hline & 2001-04 & Alternaria sp. & $7 / 29$ \\
\hline & 2007-09 & Botrytis cinerea & $1 / 25$ \\
\hline \multirow[t]{2}{*}{ Nodding thistle } & 2007-09 & Phoma exigua & $2 / 16$ \\
\hline & 2007-09 & Colletotrichum sp. & $1 / 16$ \\
\hline
\end{tabular}

and New Zealand native Rubus is not known, these are not economic plants, nor are they listed as endangered species" (Barton 2005). Rightly or wrongly a decision was made in Australia that any collateral damage was an acceptable outcome for their management of blackberry. Unfortunately this decision was made on an incorrect assumption that all susceptible endemic species, such as $R$. schmidelioides, were not endangered. However, in many parts of New Zealand this species is now absent or rare and regionally threatened (Stanley et al. 2005). This case study emphasises the importance of close Australasian collaboration when highly mobile biocontrol agents are being considered.

Additional strains of $P$. violaceum were officially permitted for release in Australia in 1991 and 2004 (Gomez et al. 2006). It is therefore recommended that ongoing checks of New Zealand's susceptible native Rubus species are made to ensure these novel 
Australian strains are not contributing to any non-target damage or further regional decline of these plants.

No symptoms of non-target attack by the remaining four pathogens were observed on any of the species inspected. Previous host range testing demonstrated all of these agents damaged their respective target weed but did not infect any non-target species (Jenkins 1998; Fröhlich et al. 1999; Kleinjan et al. 2004). The present field inspections further confirmed the monospecific status of all four of these pathogens in New Zealand.

The first release of a fungus for classical biocontrol of a weed occurred in 1971, when Puccinia chondrillina was introduced into Australia for the control of skeletonweed (Chondrilla juncea) (Julien \& Griffiths 1998). To date, 26 species of fungi, originating from 15 different countries, have been used as classical biocontrol agents against over 26 species of weeds in seven countries (Barton 2004). No reports were uncovered of deliberately introduced fungi unexpectedly attacking non-target plants after release (Barton 2004). The present study also confirms the low risk status for use of approved pathogens for weed biocontrol. Of the five case studies, only the mist flower smut has been deliberately introduced to New Zealand, where it has remained monospecific whilst proving a highly effective agent against its target plant (Barton et al. 2007). A parallel survey of the 14 invertebrate case studies by Paynter et al. (2004), also reported that that the overall reliability of host-range testing in past weed biocontrol programmes for New Zealand has been high.

Predictions of field host-range in classical weed biocontrol programmes undertaken in New Zealand have been based on a combination of thorough host-range testing, knowledge of the taxonomy of the agent, the target weed and non-target species, and knowledge of the ecology of the agent in its native range. This has ensured that the deliberate introduction of exotic pathogens has been an environmentally safe and sustainable method for weed control.

\section{ACKNOWLEDGEMENTS}

The authors would like to thank the following people for assistance with providing or locating field sites and sample collection: the many staff of the national collective of regional councils and the Department of Conservation (DOC), Ines Schonberger, Tony Barton, R \& B Somerfield, Ian Turk (NZ Boysenberry Council), Rick and Donna Nicholson, Freefall Orchard (Jules and Tony), Barry Hartley, Paula and Mark Pardington, Duncan Smeaton, Rod McAdam and the Ohinewai Farmers Group Inc. We also thank Simon Fowler and Quentin Paynter for scientific advice; Eric McKenzie and Shaun Pennycook for biosystematics advice about pathogens; and Ewen Cameron and Mei Nee Lee (Auckland Museum), Rebecca Stanley (ARC) and Peter De Lange (DOC) for botanical advice. Funding was provided by the New Zealand Foundation for Research, Science and Technology, Contract no. C09X0210 and C09X0504.

\section{REFERENCES}

Barton J 2004. How good are we at predicting the field host-range of fungal pathogens used for classical biological control of weeds? Biological Control 31: 99-122.

Barton J 2005. No surprise that Aussie rust misbehaves. What's New In Biological Control Of Weeds? 32: 6-8.

Barton J, Fowler SV, Gianotti AF, Winks CJ, de Beurs M, Arnold GC, Forrester G 2007. Successful biological control of mist flower (Ageratina riparia) in New Zealand: agent establishment, impact and benefits to native flora. Biological Control 40: 370-385.

Briese DT, Walker A 2002. A new perspective on the selection of test plants for evaluating the host-specificity of weed biological control agents: the case of Deuterocampta quadrijuga, a potential insect control agent of Heliotropium amplexicaule. Biological Control 25: 273-287. 
Bruzzese E, Hasan S 1986a. Infection of Australian and New Zealand Rubus subgenera Dalibarda and Lampobatus by the European blackberry rust fungus Phragmidium violaceum. Plant Pathology 35: 413-416.

Bruzzese E, Hasan S. 1986b. Host specificity of the rust Phragmidium violaceum (Schultz) Winter. A potential biological control agent of European blackberry. Annals of Applied Biology 108: 585-596.

Cripps MG, Edwards GR, Waipara NW, Bourdôt GW, Saville DJ, Fowler SV 2009. Does transmission of the rust pathogen, Puccinia punctiformis, require stem mining vectors? Biocontrol Science and Technology 19: 447-454.

Cunningham GH 1927. Natural control of weeds and insects by fungi. New Zealand Journal of Agriculture 34: 244-251.

Evans HC 2000. Evaluating plant pathogens for biological control of weeds: an alternative view of pest risk assessment. Australasian Plant Pathology 29: 1-14.

Fowler SV, Syrett P, Hill RL 2000. Success and safety in the biological control of environmental weeds in New Zealand. Austral Ecology 25: 553-562.

Fröhlich J, Fowler SV, Gianotti AF, Hill R, Killgore ES, Morin L, Sugiyama L, Winks CJ 1999. Biological control of mist flower (Ageratina riparia, Asteraceae) in New Zealand. Proceedings of the 52nd New Zealand Plant Protection Conference: 611.

Goettel MS, Hajek MS, Siegel JP, Evans HC 2001. Safety of fungal biocontrol agents. In: Butt TM, Jackson CW, Magan N ed. Fungi as Biocontrol Agents. CABI Bioscience, Wallingford, UK. Pp. 347-375.

Gomez DR, Evans KJ, Harvey PR, Bakera J, Barton J, Jourdan M, Morin L, Pennycook SR, Scott ES 2006. Genetic diversity in the blackberry rust pathogen, Phragmidium violaceum, in Europe and Australasia as revealed by analysis of SAMPL. Mycological Research 110: 423-430.

Harman HM, Waipara NW, Winks CJ, Smith LA, Peterson PG, Wilkie JP 2008. Natural enemies of bridal creeper, Asparagus asparagoides, in New Zealand. New Zealand Plant Protection 61: 362-367.

Howarth FG 1991. Environmental impacts of classical biological control. Annual Review of Entomology 36: 485-509.

Jenkins T 1995a. Fungal biological control of Hieracium spp. PhD Thesis, University of Canterbury, New Zealand. 277 p.

Jenkins T 1995b. Rust biological control of Hieracium. Re-collection and testing of isolates. Unpublished Hieracium Control Trust Report, Christchurch, New Zealand. September 1995. 15 p.

Jenkins T 1998. Preparation for introduction of further rust isolates. Hieracium Control Trust Report, Christchurch, New Zealand. March 1998. 12 p.

Julien MH, Griffiths MW 1998. Biological Control of Weeds. A World Catalogue of Agents and Their Target Weeds, fourth ed. CAB International, Wallingford, UK. $235 \mathrm{p}$.

Kleinjan CA, Morin L, Edwards PB, Wood AR 2004. Distribution, host range and phenology of the rust fungus Puccinia myrsiphylli in South Africa. Australasian Plant Pathology 33: 263-271.

Louda SM, Kendall D, Connor J, Simberloff D 1997. Ecological effects of an insect introduced for the biological control of weeds. Science 277: 1088-1090.

Louda SM, Pemberton RW, Johnson MT, Follett PA 2003. Nontarget effects - the Achilles Heel of biological control? Annual Review Entomology 48: 365-396.

Marks GC, Pascoe IG, Bruzzese E 1984. First record of Phragmidium violaceum on blackberry in Victoria. Australasian Plant Pathology 13: 12-13.

McKenzie EHC 1998. Rust fungi of New Zealand - an introduction, and list of recorded species. New Zealand Journal of Botany 36: 233-271. 
Osterbauer N, Trippe A, French K, Butler T, Aime MC, McKemy J, Bruckart WL, Peerbolt T, Kaufman D 2005. First report of Phragmidium violaceum infecting Himalaya and evergreen blackberries in North America. Plant Health Progress Online doi:10.1094/PHP-2005-0923-01-BR.

Paynter QE, Fowler SV, Gourlay AH, Haines ML, Harman HM, Hona SR, Peterson PG, Smith LA, Wilson-Davey JRA, Winks CJ, Withers TM. 2004. Safety in New Zealand weed biocontrol: A nationwide survey for impacts on non-target plants. New Zealand Plant Protection 57: 102-107.

Pennycook SR 1989. Plant diseases recorded in New Zealand. Volume 1-3. Plant Diseases Division, DSIR, Auckland, New Zealand.

Sheppard AW, Hill R, DeClerck-Floate RA, McClay A, Olckers T, Quimby Jr. PC, Zimmermann HG 2003. A global review of risk-benefit-cost analysis for the introduction of classical biological control agents against weeds: a crisis in the making? Biocontrol News and Information 24: 91-108.

Simberloff D, Stiling P 1996. How risky is biological control? Ecology 77: 19651974.

Stanley R, de Lange P, Cameron EK 2005. Auckland regional threatened and uncommon vascular plants list. Auckland Botanical Society Journal 60: 152-158.

Waipara NW, Winks CJ, Paynter QE, Riding N, Day MD 2009. Prospects for the biological control of Lantana camara (Verbenaceae) in New Zealand. New Zealand Plant Protection 62: 50-55.

Waipara NW, McKenzie EHC, Harman HM, Winks CJ, Park D 2006. First record of bridal creeper rust, Puccinia myrsiphylli, a classical biocontrol agent of the environmental weed bridal creeper, Asparagus asparagoides, in New Zealand. Australasian Plant Disease Notes 1: 23-24.

Wapshere AJ 1974. A strategy for evaluating the safety of organisms for biological weed control. Annals of Applied Biology 77: 201-211. 